\title{
Groundwater flow and storage within an alpine meadow-talus complex
}

\author{
A. F. McClymont, M. Hayashi, L. R. Bentley, D. Muir, and E. Ernst \\ Department of Geoscience, University of Calgary, 2500 University Drive NW, T2N1N4, Calgary, AB, Canada \\ Received: 4 January 2010 - Published in Hydrol. Earth Syst. Sci. Discuss.: 25 February 2010 \\ Revised: 3 May 2010 - Accepted: 6 May 2010 - Published: 1 June 2010
}

\begin{abstract}
The different types of geological deposits and rock formations found in alpine watersheds play key roles in regulating the rate and timing of runoff to mountain rivers. Talus and alpine meadows are dominant features in these areas, but scant data exist for their capacity to store and transmit groundwater. To gain further understanding of these processes, we have undertaken a combined geophysical and hydrological study of a small $\left(2100 \mathrm{~m}^{2}\right)$ alpine meadow and surrounding talus within the Lake O'Hara watershed in the Canadian Rockies. Several intersecting ground-penetrating radar (GPR) and electrical resistivity tomography (ERT) profiles and a seismic refraction profile were acquired to map the thickness of the talus and to image the topography of the bedrock basin that underlies the meadow. From analysis of the GPR and seismic profiles, we estimate that the talus deposits are relatively thin $(<6 \mathrm{~m})$. Combined interpretations from the GPR and ERT data show that the fine-grained sediment comprising the meadow basin has a total volume of ca. $3300 \mathrm{~m}^{3}$ and has a maximum thickness of ca. $4 \mathrm{~m}$. Annual snow surveys and stream gauging reveal that the total input volume of snowmelt and rainfall to the meadow basin is several times larger than its groundwater storage capacity, giving rise to low total-dissolved species concentrations $(14-21 \mathrm{mg} / \mathrm{L})$ within the meadow groundwater. Observations from four piezometers established on the meadow show that the water table fluctuates rapidly in response to spring snowmelt and precipitation events but otherwise maintains a relatively stable depth of $0.3-0.4 \mathrm{~m}$ below the meadow surface during summer months. A slug test performed on one of the piezometers indicated that the saturated hydraulic conductivity of the shallow meadow sediments is $2.5 \times 10^{-7} \mathrm{~m} / \mathrm{s}$.
\end{abstract}

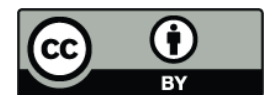

Correspondence to: A. F. McClymont (alastairmcclymont@gmail.com)
We suggest that a bedrock saddle imaged underneath the southern end of the meadow forms a natural constriction to subsurface flow out of the basin and helps to maintain the stable water-table depth.

\section{Introduction}

In western regions of Canada and the United States alpine watersheds play an important role in the supply and delivery of freshwater to surrounding lowland areas. During winter months, most of this water is locked up in the form of seasonal mountain snowpacks, which is then released into alpine streams by subsequent melting during spring. Recent hydrological field studies in high-elevation watersheds have shown that during this high-flow melt period the contribution of subsurface flow to alpine streams can be as large as, if not larger than, that from surface flow (e.g. Sueker et al., 2000; Clow et al., 2003; Liu et al, 2004; Hood et al., 2006). In addition, although as much as $80 \%$ of total annual flow to alpine streams occurs during the Spring melting period from May to July (e.g. Kattelmann and Elder, 1991; Campbell et al., 1995), a significant component is stored as groundwater within the alpine watersheds that is slowly released during the low-flow period over the remaining nine months of the year (Clow et al., 2003; Hood et al., 2006). Understanding the water-storage capacity and other hydrogeological parameters of typical geological deposits within alpine watersheds (e.g., moraines, talus, and bedrock) is therefore critical to simulating and predicting regional-scale hydrological processes (Clow et al., 2003; Bales et al., 2006).

Talus and snow avalanche boulder formations are closely related types of slope deposit that occur extensively in alpine watersheds. They represent accumulations of rock debris that

Published by Copernicus Publications on behalf of the European Geosciences Union. 
have been transported from cliff faces, usually in response to glacial debuttressing of valley rockwalls (Ballantyne, 2002). Whereas snow avalanche deposits result from the erosion and entrainment of rocks by snow avalanches, talus slopes form mainly as a consequence of rockfall (Jomelli and Francou, 2000). Although rockfall and snow avalanches are the dominant depositional mechanisms behind talus and snow avalanche deposits, debris flows and rainwash and snowmelt water processes may also influence their formation (White, 1981; Bertran et al., 1997). In addition, between these two types of landform there exist transitional deposits that result from some combination of all the different mechanisms described above (Jomelli and Francou, 2000).

Scant field data exist for in situ physical hydrological processes within alpine slope deposits such as talus and snow avalanche boulder formations. Pierson (1982) investigated the hydrological properties of different types of scree slope deposit in New Zealand and inferred that the hydrological response would be strongly dependent on certain sedimentological characteristics, including the degree of stratification and the amount of fine-grained material present. From geomorphological mapping, seismic refraction measurements and porosity and permeability estimates, Clow et al. (2003) established that talus slopes were the primary ground water reservoir within an alpine catchment in the Colorado Rocky Mountains with an estimated maximum storage capacity as large as the total annual discharge from the basin. Moreover, tracer tests and stream gauge measurements revealed that ground water flowing from talus could account for greater than $75 \%$ of streamflow during storms and the winter base flow period. Caballero et al. (2002) conducted tracer tests of slope deposits in a high Andean valley and measured substantially different delay times for subsurface flow within a talus slope and lateral moraine of 24 and $48 \mathrm{~h}$, respectively. Other physical properties of slope deposits that can be used to infer hydrological characteristics, including debris volumes and internal structures, have been determined using geophysical methods such as ground-penetrating radar (GPR), electrical resistivity tomography (ERT), and seismic refraction methods (e.g. Sass and Wollny, 2001; Clow et al., 2003; Schrott et al., 2003; Sass, 2006, 2007).

In terms of surface area, grassland meadow coverage is not usually as extensive as that of slope deposits in alpine watersheds (e.g. Clow et al., 2003). Nevertheless, the common occurrence of alpine meadows in the areas between talus and stream channels within many alpine watersheds (see Fig. 5 in Caballero et al., 2002) suggests that the soil deposits beneath alpine meadows represent important hydrogeological units that can control the flow of groundwater from fast-response units like talus to alpine streams and rivers. Depending on the residence time of groundwater in the meadow deposits, water chemistry may be affected by the complex biogeochemical processes such as nitrate removal. Sueker et al. (2001) reported that areas with established vegetation, such as subalpine meadows, can play an important role in mitigating the negative effects of atmospheric nitrogen deposition. In addition to the hydrological importance, alpine meadows have important ecological functions such as the food source for herbivores in an environment where vegetation cover is limited (Roach et al., 2001).

Few studies on groundwater hydrology in alpine meadows are found in the literature. Previous studies mainly focus on riparian meadows in high-elevation watersheds. The watertable dynamics of these riparian meadows are strongly influenced by the interaction of groundwater and streams (e.g. Loheide et al., 2009). While riparian meadows have important eco-hydrological functions in alpine environments, alpine meadows occur in other settings. For example, alpine meadows are commonly found at toes of talus, and talus-meadow complexes serve as the source areas of alpine streams. The water table dynamics of this type of meadow are expected to be controlled by the input of water from talus (and bedrock cliffs above) and the output through surface and subsurface drainage. However, little is known about the hydrology of talus-meadow complexes. As part of an investigation into the properties of groundwater flow and storage of different geological landforms within an alpine watershed in the Canadian Rockies, we conducted a combined geophysical and hydrological study of a talus-meadow complex. The objectives of this study are to: (1) delineate the subsurface structures of a typical talus-meadow complex using geophysical imaging, (2) identify the factors that control the water-table dynamics, and (3) estimate the groundwater storage volume and residence time.

\section{Study site}

The study was conducted in the Opabin sub-watershed within the Lake O'Hara watershed, located on the western edge of the continental divide within the Canadian Rockies (Fig. 1). The Opabin watershed has a catchment area of $5 \mathrm{~km}^{2}$ and ranges in elevation from 2050 to $3490 \mathrm{~m}$ a.s.l. Bedrock within the watershed comprises interbedded quartzite, quartzose sandstone, siltstone, and grey shale metasediment rocks of the Cambrian Gog Group with minor outcrops of carbonate rocks (Price et al., 1980). Late Quaternary glaciofluvial deposits within the valley are derived from these formations. Major landcover units within the watershed include bedrock $(40 \%)$, talus $(25 \%)$, moraine materials $(15 \%)$, and meadows and sub-alpine forest $(20 \%)$. Mean annual precipitation is $1000-1200 \mathrm{~mm}$ depending on the elevation, and mean monthly temperature is $-9.6^{\circ} \mathrm{C}$ in January and $10.4{ }^{\circ} \mathrm{C}$ in July. The watershed is snow-covered for eight months of the year. Opabin Glacier lies at the southeastern end of the watershed and runoff and groundwater flow is to the northwest. The watershed is drained by Opabin Creek, which flows into Lake O'Hara (Fig. 1b). 


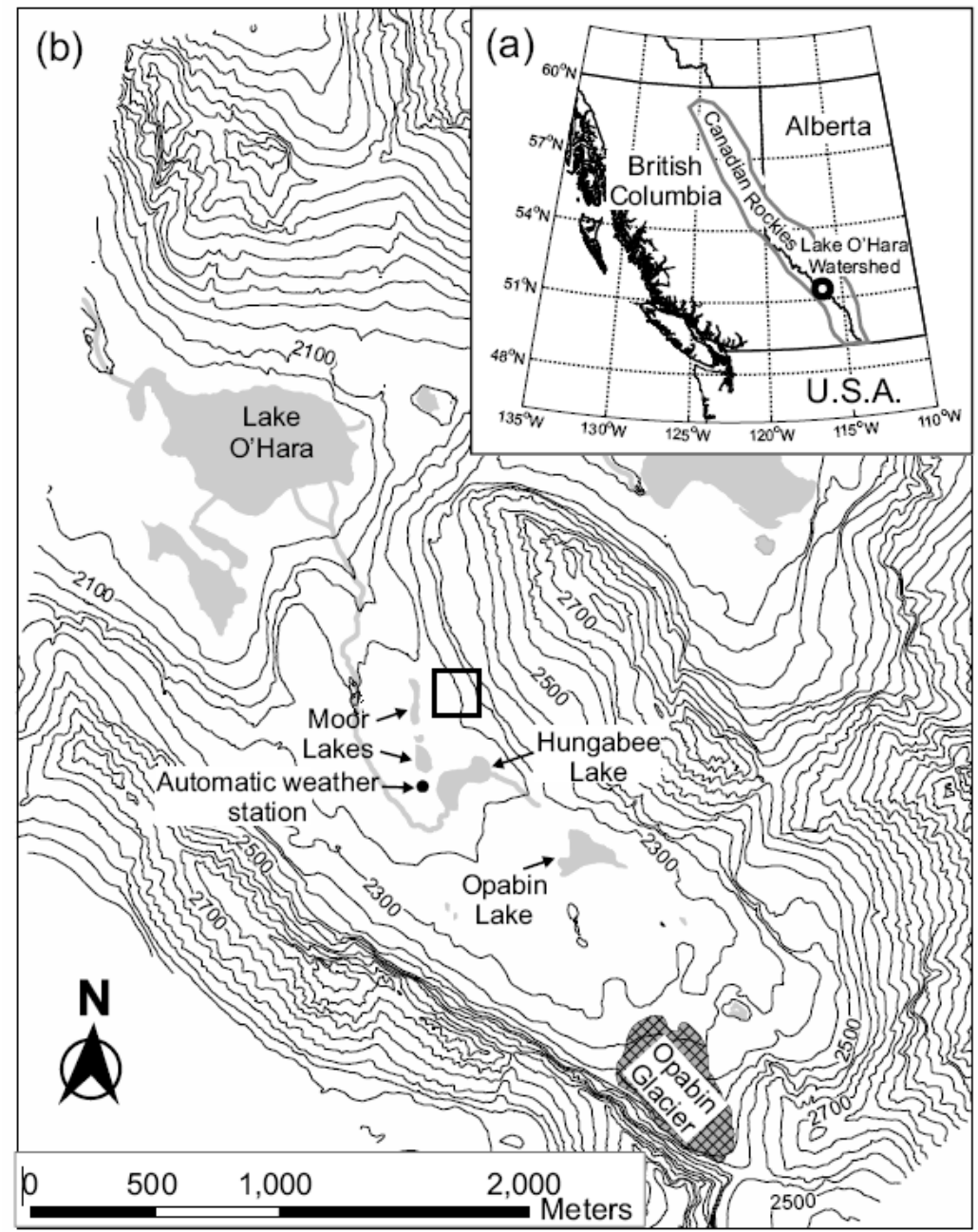

Fig. 1. Topographic map of the Opabin watershed showing Opabin Creek (gray solid line), major lakes (gray bodies), a glacier (stippled), and the automatic weather station (AWS). Black square indicates the location of the hydrological and geophysical surveys on the talus-meadow complex shown in Figs. 2 and 3. Contour interval is $50 \mathrm{~m}$. The insert shows the site location in North America.

Our study area lies at the foot of a steep valley wall on the northeastern side of the watershed (Figs. 1b, 2, and 3). At this location, a series of talus cones are located on the margin of a small $\left(2100 \mathrm{~m}^{2}\right)$ alpine meadow that is underlain by a deposit of relatively fine-grained debris within a bedrock depression. Although the meadow is small, thousands of similarly sized alpine meadows exist in the Rocky Mountains and, therefore, they represent a fundamental hydrologic landscape unit. The bedrock at this location is quartzite of the Lower Cambrian Fort Mountain Formation, which has an approximate strike of $150^{\circ}$ and dips $10^{\circ}$ to the east (Hislop, 2008). Parts of the talus are covered in grass and show evidence for the development of a soil layer, suggesting that, unlike active talus in other parts of the valley, rates of recent debris accumulation in these formations have been relatively low. Water that infiltrates into the talus drains into the small basin underlying the meadow. A forested linear ridge of bedrock on the west- ern side of the meadow forms a barrier to the flow of surface runoff and entrained sediment, directing intermittent stream flow to a notch at the southern end of the basin, where it flows into a northwest-trending gully (Figs. 2 and 3). Slow groundwater seepage has been observed from fractures in the small cliff on the western side of the bedrock ridge, indicating that a small fraction of the water that drains into the basin escapes through bedrock.

\section{Field methods}

To investigate the internal structures and physical properties of the debris cone and basin deposits and to gain an estimate of the depth to bedrock, a series of ground-penetrating radar (GPR), electrical resistivity tomography (ERT), and seismic refraction profiles were acquired (Fig. 3a). All of 
Table 1. Geophysical data acquisition parameters.

\begin{tabular}{lll}
\hline GPR & ERT & Seismic refraction \\
\hline System: PulseEKKO Pro & System: 48-channel Iris Syscal Pro & System: 24-channel Geometrics \\
$\begin{array}{l}\text { Nominal frequency: } 50 \mathrm{MHz} \\
\text { Trace spacing: } 0.25 \mathrm{~m}\end{array}$ & Configuration: Wenner & Source: sledgehammer on plate \\
Antenna separation: $2 \mathrm{~m}$ & Noctrodes: $30 \mathrm{~cm}$ steel stakes & Geophones: $10 \mathrm{~Hz}$ vertical \\
Sampling rate: $0.8 \mathrm{~ns}$ & Output voltage: 400 or $800 \mathrm{~V}$ & Number of shots: 7 \\
Recording window: $1000 \mathrm{~ns}$ & & Nominal shot spacing: $12 \mathrm{~m}$ \\
Stacks: 32 & & Nominal geophone spacing: $1 \mathrm{~m}$ \\
& & Sampling rate: $1 \mathrm{~ms}$ \\
& & Recording window: $250 \mathrm{~ms}$ \\
\hline
\end{tabular}

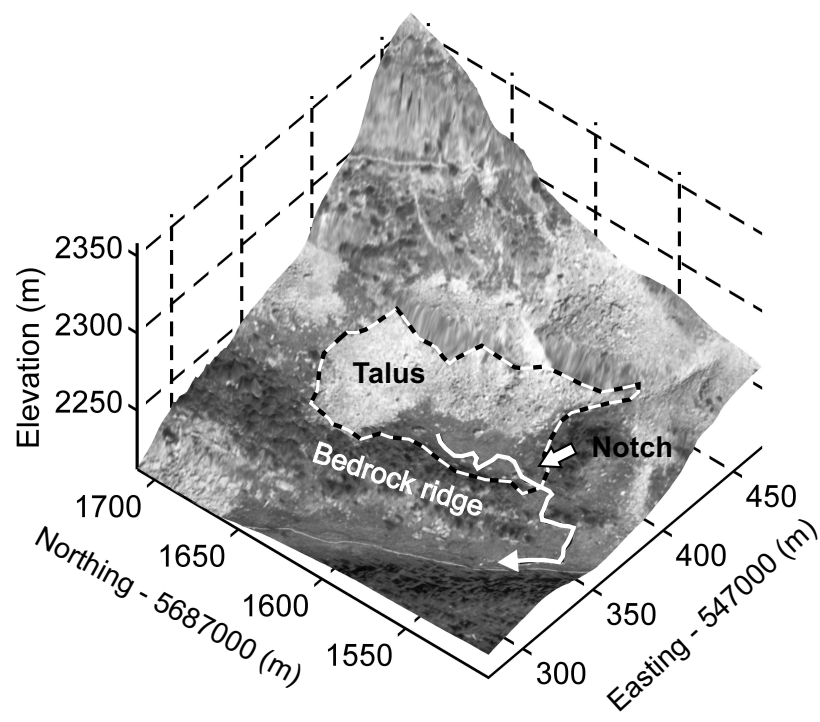

Fig. 2. Three-dimensional photo-draped digital elevation model of the talus-meadow complex (outlined by dashed line). White line small stream that flows intermittently across the meadow and drains into a neighboring gully. No vertical exaggeration. Coordinates are in UTM grid.

the geophysical data were obtained during the summers of 2006 and 2007, when the study area was free of snow. Coordinates for each profile were measured using either a differential GPS or a laser theodolite. Acquisition parameters for each technique are listed in Table 1.

\subsection{Ground-penetrating radar profiles}

In a GPR survey, electromagnetic pulses are transmitted into the ground, where they are reflected off boundaries of contrasting electrical and electromagnetic properties. Although its depth penetration within standard geological materials is often limited to a few metres, the high-resolution imaging capabilities of GPR have been used to delineate subsurface structures in archeological (e.g., Davis et al., 2000), glaciological (e.g. Moran et al., 2000), and other geological investigations (e.g., Jol and Smith, 1991; Beres et al., 1999; Sass, 2006).

We acquired five GPR profiles with various orientations over the talus, meadow, and parts of the bedrock (Fig. 3a). Processing steps included the initial application of a standard dewow filter to remove low-frequency electromagnetic inductive noise. After aligning first arrivals and correcting to time zero, the GPR traces were scaled by dividing them by smoothed versions of their amplitude envelopes (Gross et al., 2003). A band-pass filter was then applied to remove highand low-frequency noise. Finally, each trace was corrected from time to depth using an average velocity determined by analyzing the normal moveout of reflections on several common-midpoint profiles (CMPs) that were recorded over talus and bedrock at the site $(0.12 \mathrm{~m} / \mathrm{ns}$; red circles in Fig. $3 \mathrm{a}$; e.g., Annan, 2005). Velocities within the fine-grained soil layer underlying the meadow are expected to be significantly slower. However, because strong attenuation of electromagnetic waves traveling through this layer prevented us from imaging structures within or beneath the meadow, we consider the average velocity representative of talus and bedrock to be the most appropriate for displaying our depth-corrected GPR cross-sections.

\subsection{Electrical resistivity tomography profiles}

Resistivity is a measure of how resistive a volume of material is to the flow of electric current. Because it is sensitive to changes in pore-water and pore-space geometry in rocks, the electrical resistivity method is very effective at detecting changes in subsurface water content and delineating different geological materials. In typical electrical resistivity surveys, a low-frequency alternating current is injected into the ground through a pair of electrodes and a potential difference is measured between a separate pair of receiver electrodes. 
By using an array of electrodes and by recording on different electrode pairs, various subsurface current paths can be sampled. Inversion techniques can then be used to reconstruct an electrical resistivity tomogram of the subsurface based on measurements made from all the different electrode combinations (e.g., Loke and Barker, 1996). Electrical resistivity tomography (ERT) has proven to be a particularly effective method for mapping subsurface materials in alpine environments (e.g. Kneisel et al., 2000; Maurer and Hauck, 2007).

Four ERT profiles were recorded across the site. As shown in Fig. 3, profiles ERT1 and ERT2 (green lines) were recorded along the same lines as profiles GPR1 and GPR2 (red lines). An Iris Syscal Pro 48-channel multi-electrode system was used to record the profiles, which varied in length from 58 to $130 \mathrm{~m}$. To ensure good lateral resolution of buried structures, we used the moving gradient array electrode geometry for each profile (Dahlin and Zhou, 2004). A rollalong technique was used to record the longer profiles that required more than 48 electrode locations.

In general, contact resistances between consecutive electrodes planted on the meadow area were low, indicating good electrical coupling with the subsurface. To improve current injection on parts of the debris cones where relatively high contact resistances were encountered $(>50 \mathrm{k} \Omega)$, the steel electrode stakes were affixed to wet sponges before planting into the ground (e.g. Maurer and Hauck, 2007). For each combination of current- and potential-electrode pairs, the average of three measurements was recorded. Spurious data points were removed from the resistivity data sets prior to inversion. Resistivity tomograms of each profile data set were computed using the RES2DINV inversion code; an iterative Gauss-Newton smoothness-constrained least-squares algorithm (Loke and Barker, 1996; Loke and Dahlin, 2002). This algorithm uses a finite-element calculation for the forward problem and topography is incorporated by using a distorted finite-element mesh. Cell widths used for each model mesh were assigned horizontal dimensions equal to half the electrode spacings of approximately $2 \mathrm{~m}$. Because we expected relatively sharp geological boundaries and because we wanted to limit the influence of outliers in our datasets, we used the robust $\left(\mathrm{L}_{1}\right.$-norm $)$ model and data inversion constraints. For each inverted profile, convergence was reached after no more than four iterations and root-meansquare (RMS) errors were in the range of 5 to $7 \%$.

The resolution of each model cell in the tomograms was assessed by applying the depth-of-investigation (DOI) test (Oldenburg and Li, 1999; Marescot et al., 2003). In this test, the data were inverted twice using two different initial models; the first with model cells assigned a single resistivity value one tenth of the average apparent resistivity and the second with a value ten times the average apparent resistivity. After three iterations of each inversion, model cells that showed little dependence on the initial resistivity model used (i.e., that converged to similar resistivity values after each inversion) had small DOI values; model cells that produced

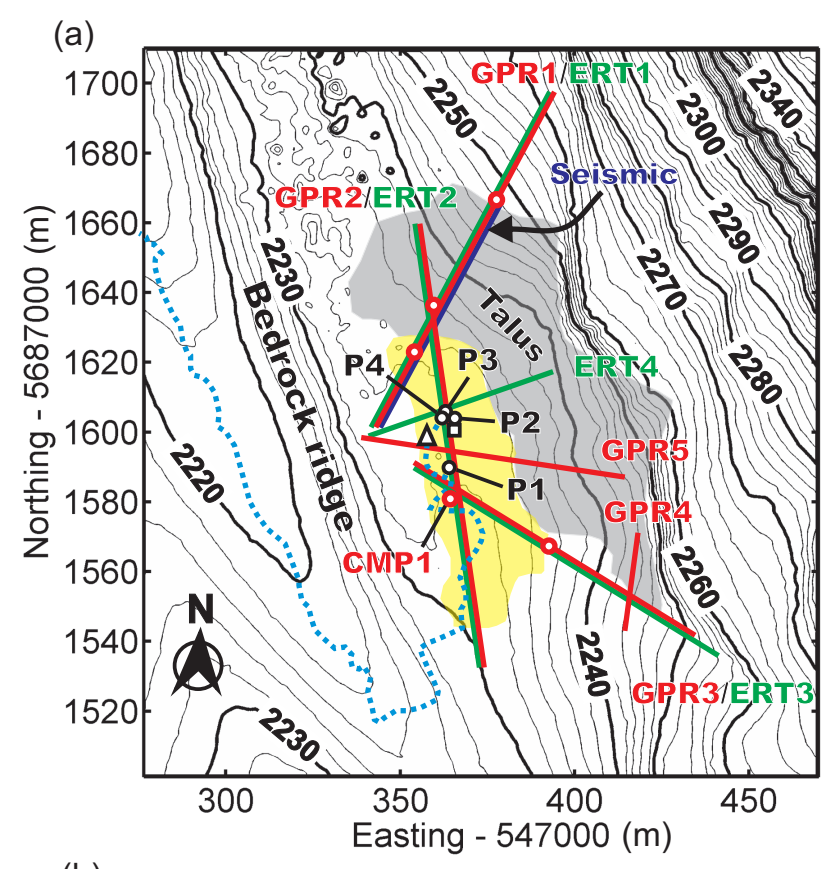

(b)

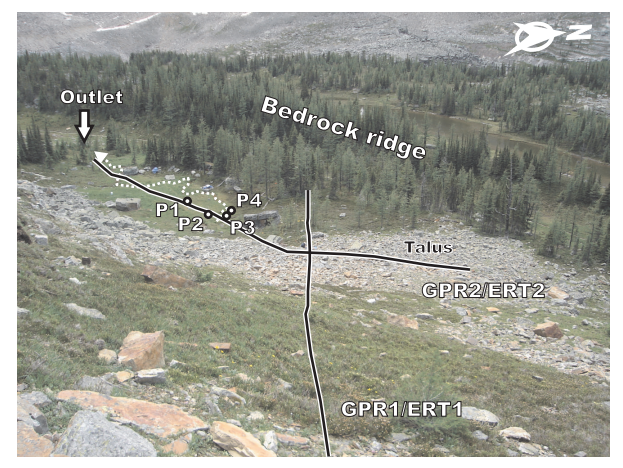

Fig. 3. (a) Contour map of the same region shown in Fig. 2 with location of the five GPR profiles (red lines), centers of five common-midpoint (CMP) GPR profiles (red circles), four ERT profiles (green lines), and the shot and receiver array of the seismic refraction profile (dark blue line). Yellow body shows the area of the alpine meadow and gray body the area of the talus cones. Also shown are the locations of four piezometers (black circles), the monitoring weir (triangle), and the excavated soil pit (square). Blue dotted line - course of the small stream. Contour elevations are in meters. (b) Photo of the talus-meadow complex taken from the top of profile GPR1/ERT1 and looking to the southwest. Also shown are the locations of piezometers P1-P4 and profile GPR2/ERT2.

different resistivity values had large DOI values. To improve our interpretations of the tomograms, we opted not to plot model cells with normalized DOI values $>0.2$.

\subsection{Seismic refraction profile}

Because of its ability to discriminate relatively high-velocity bedrock material from low-velocity overburden, the seismic refraction method provides a useful tool for characterizing 
sedimentary deposits in alpine settings (e.g. Hoffmann and Schrott, 2002; Musil et al., 2002; Sass, 2006). In a typical first-arrival seismic refraction experiment, the subsurface compressional-wave (P-wave) velocity distribution is determined based on the time it takes the energy produced by a seismic source to reach an array of offset receivers. These travel-time data can be used as input into a tomographic inversion routine to calculate a representative subsurface velocity model (e.g. Zelt and Smith, 1992; Lanz et al., 1998; Musil et al., 2002).

A single seismic refraction profile was acquired across the northern part of the meadow-talus complex (blue line in Fig. 3a). Seven shot gathers were recorded with an array of 48 vertical-component geophones. For each shot a seismic source was generated by striking an $8 \mathrm{~kg}$ sledgehammer against a high-density plastic plate. To improve the signal-tonoise $(S / N)$ ratio of first arrivals, shots were repeated at each shot point and the data stacked as needed.

Following field acquisition, the traces on each shot gather were scaled using a $100 \mathrm{~ms}$ automatic-gain control (AGC) filter to enhance first arrivals. Although most first breaks on each shot record were relatively easy to pick, low $S / N$ ratios meant that some first breaks could not be identified on traces with a large shot-receiver offset (e.g. Fig. 7). By analyzing $S / N$ ratios, we assigned uncertainties to all of our first-arrival picks that ranged from \pm 3 to $\pm 6 \mathrm{~ms}$.

Picked first-arrivals from all of the shot gathers were used as input into the INV2D seismic inversion program. This program uses a finite-difference eikonal forward solver to compute travel-time fields on a regular grid (Lanz et al., 1998; Musil et al., 2002). This program uses an initial model mesh and adjusts iteratively the model parameters based on a damped least-squares solution. Convergence is reached once travel times calculated from the updated velocity model fit observed first-arrival travel-time picks to an appropriate level of misfit. We used a regular model mesh with total horizontal and vertical dimensions of $86 \mathrm{~m}$ and $80 \mathrm{~m}$, respectively and cell dimensions of $2 \times 2 \mathrm{~m}$. Our initial starting model had velocities of $300 \mathrm{~m} / \mathrm{s}$ at the top of the mesh that increased linearly in the vertical direction at a rate of $40 \mathrm{~m} / \mathrm{s}$ per model cell. Topography was incorporated into the model by setting model cells above the ground surface to the velocity of air and keeping them fixed during the inversion. Model convergence was reached after eight iterations, at which point the RMS travel-time error had reduced to $3 \mathrm{~ms}$.

\subsection{Hydrological instrumentation and measurements}

Meteorological data including precipitation were recorded at an automatic weather station located approximately $400 \mathrm{~m}$ southwest of the site (Fig. 1b). Snow accumulation data at the study site were extracted from a snow survey data set for the entire Opabin sub-watershed, collected during 1720 April in 2007 and 2008. Ninety-nine snow depth measurements were taken in and around the study site in 2007 and six depth measurements in 2008. Snow water equivalent (SWE) for each depth point was estimated using the snow depth-density relationship, which was derived from all density measurements (236 points in 2007 and 144 in 2008) obtained in the entire sub-watershed in each year.

A 1.1-m deep soil pit was excavated in July 2007 (square in Fig. 3a) to collect soil samples and install soil moisture and temperature sensors (Stevens, Hydra Probe II). Soil samples were collected from depths of $0.09,0.10,0.31,0.87$, and $0.95 \mathrm{~m}$ in stainless steel cylinders having an internal volume of $100 \mathrm{~cm}^{3}$. The water content of the samples was calculated from the difference between the wet weight and ovendry weight. Soil moisture/temperature sensors were installed horizontally at depths of $0.37,0.63$, and $0.90 \mathrm{~m}$, and the pit was back filled with the local soil.

Four piezometers were installed in the meadow (black circles in Fig. 3a) in July and August 2007. They were made of $P V C$ pipes having an inside diameter of $0.05 \mathrm{~m}$, with the bottom $0.3 \mathrm{~m}$ perforated to serve as a screen. The piezometers were installed in $0.08-\mathrm{m}$ diameter hand-augered holes. The annulus space around the screen was filled with filter sand, and the rest was filled with bentonite. The depth to the bottom of screens ranged from 0.63 to $1.07 \mathrm{~m}$. The water level in piezometer $\mathrm{P} 4$ was monitored using pressure transducers (in situ, Level-Troll 500), which recorded pressure every 10 minutes, and water levels in all piezometers were measured weekly using a water level sounder.

A 90-degree V-notch weir was installed in a channel draining the meadow (triangle in Fig. 3a) to monitor surface water discharge. The flow rate was measured manually using a bucket and stopwatch on a weekly schedule during JulySeptember of each year, from which a stage-discharge relationship for the weir was developed. Surface water samples were collected from the channel on a biweekly schedule during July-September 2007, and analyzed for major ions using ion-exchange chromatography and for alkalinity by titration.

The saturated hydraulic conductivity of the surface soil was estimated using a steel ring infiltrometer, which had a diameter of $0.3 \mathrm{~m}$ and was driven into the soil to a depth of $0.15 \mathrm{~m}$. Water was poured into a ring while maintaining a constant head of $0.04 \mathrm{~m}$ above the ground surface until a steady flow rate was reached. The saturated hydraulic conductivity of the deeper soil was measured by conducting a slug test (Freeze and Cherry, 1979) on piezometer P4, which had a mid-screen depth of $0.92 \mathrm{~m}$. The data were interpreted using the Hvorslev (1951) formula.

\section{Results}

\subsection{Ground-penetrating radar profiles}

A processed cross-section from profile GPR1 is shown in Fig. 4a (location shown in Fig. 3a). On this and other GPR profiles, reflections from subsurface structures can be 
observed to depths of up to $20 \mathrm{~m}$. Based on observations from a nearby outcrop, we interpret the relatively continuous subhorizontal reflections observed on profile GPR1 as layering within the bedrock of metasediments. These bedrock reflections extend across most of the profile and are only interrupted by a zone of steep dipping reflections under the meadow area (between $x=10$ and $x=30 \mathrm{~m}$; Fig. 4a). Fractures that parallel these layers may provide pathways for the small amounts of groundwater that seep through the bedrock.

We interpret the steep reflections observed on profile GPR1 to be the tails of diffraction hyperbolas that originate from boulders within the small sediment-filled depression beneath the meadow (Fig. 4a). They are not apparent beneath locations outside the meadow and we suggest that this is a consequence of both strong attenuation effects beneath the meadow and the laterally varying gain functions we use to scale the GPR traces. Even though similar sized boulders can be expected within the talus rubble, the diffractions they produce probably have small amplitudes relative to the high-amplitude reflections from the underlying bedrock. In contrast, soil that occurs in the very near surface beneath the meadow is moist and probably contains a significant component of conductive clay minerals. As a consequence, the electromagnetic waves are strongly attenuated such that the diffractions from the near-surface boulders have much higher amplitudes than reflections from the underlying bedrock. Beneath the relatively dry zones of vegetated and unvegetated talus, reflections from bedrock can be traced to close to the surface, suggesting that the rubble layer is less than $5 \mathrm{~m}$ thick. Analysis of lines GPR3 and GPR5 that cover other debris cones surrounding the meadow show that the rubble layer is nowhere thicker than about $5 \mathrm{~m}$.

A similar pattern of reflections is evident on the crosssection from profile GPR2, which traverses the length of the meadow region and part of the same unvegetated talus. The same steep-dipping diffraction tails occur underneath the meadow region, partially masking subhorizontal bedrock reflections. We also note that on parts of profile GPR2 that traverse the meadow, the vertical separations between the airwave phase (AW; a non-reflective phase of energy that is transmitted directly between the antennas through the air) and the groundwave phase (GW; like the airwave phase, but transmitted through the shallowest part of the ground) are significantly larger than they are on parts of the profile that cross the debris cone (Fig. 4b). The large differences between relative groundwave-phase arrival times for the meadow and debris cone regions are the result of significant differences in their very-near surface velocities. We suggest that, compared to the debris-cone region, the slower velocities in the very-near surface of the meadow region are the result of a combination of increased subsurface water content and reduced pore spaces within the relatively fine-grained matrix of the basin fill. Towards the southern end of profile GPR2 the separation between airwave and groundwave phases decreases and bedrock reflections become more evi-

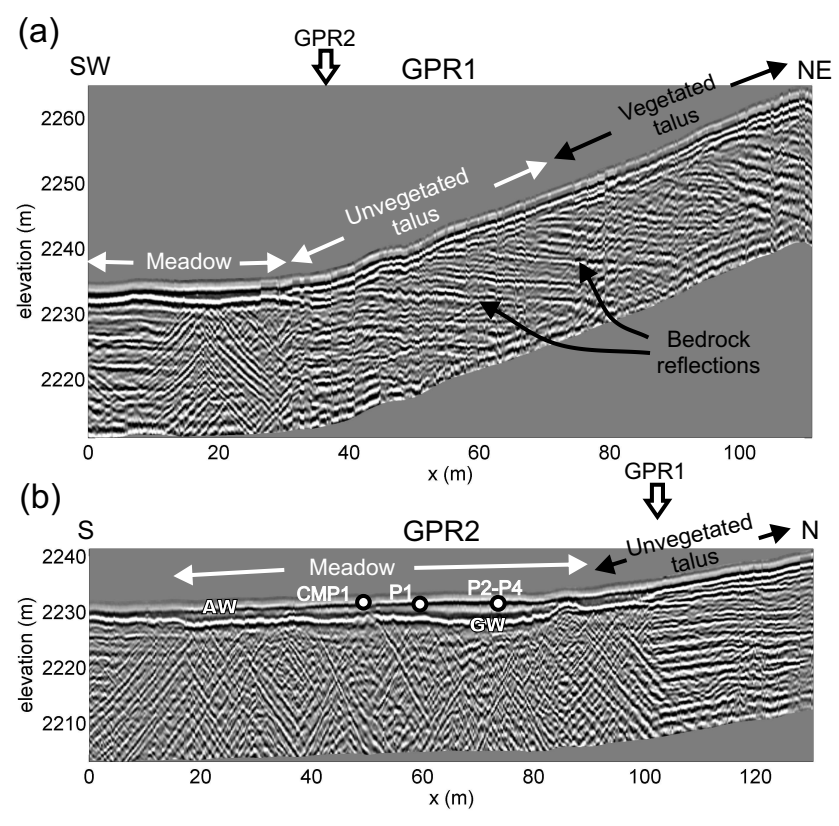

Fig. 4. Processed GPR cross-sections from profiles (a) GPR 1 and (b) GPR2. Profile locations are shown in Fig. 3a. Block arrows show where the two lines intersect. Three zones with different surface characteristics are demarcated: meadow, unvegetated talus and vegetated talus. The dots in (b) mark the projected locations of the center of the CMP1 GPR profile, piezometer P1 and the cluster of piezometers P2-P4 onto profile GPR2. AW and GW in (b) indicate the airwave and groundwave phases, respectively.

dent, indicating that the basin fill tapers out at around $x=16 \mathrm{~m}$ (Fig. 4b). We interpret this feature as a bedrock saddle that partially encloses the southern end of the basin.

Apart from CMP1, most of the CMPs analyzed were located either on talus, bedrock, or the margins of the meadow area (Fig. 3a). They yielded velocities of around $0.12 \pm 0.01 \mathrm{~m} / \mathrm{ns}$, which are typical for loose debris comprising talus deposits and indurated bedrock material (Annan, 2005; Sass, 2006). Although data from CMP1 are somewhat noisy, analysis of a relatively long-wavelength groundwave arrival phase $(\mathrm{Vg} 1)$ and a single reflection phase (Vr1) reveals a much slower velocity that is more representative of the moist fine-grained soil layer underlying the meadow $(0.065 \mathrm{~m} / \mathrm{ns}$; Fig. 5). A second groundwave phase (Vg2) with a shorter wavelength and a faster picked velocity of $0.12 \mathrm{~m} / \mathrm{ns}$ appears to originate at around $50 \mathrm{~ns}$ (Fig. 5). We interpret $\mathrm{Vg} 2$ to result from a subsurface refractor of quartzite bedrock beneath the meadow. By assuming a simple two-layer refraction model with a horizontal interface, we can solve for $z$, the thickness of the soil layer (Kearey and Brooks, 1991):

$$
z=\frac{t_{i} v_{1} v_{2}}{2 \sqrt{v_{2}^{2}-v_{1}^{2}}}
$$


(a)

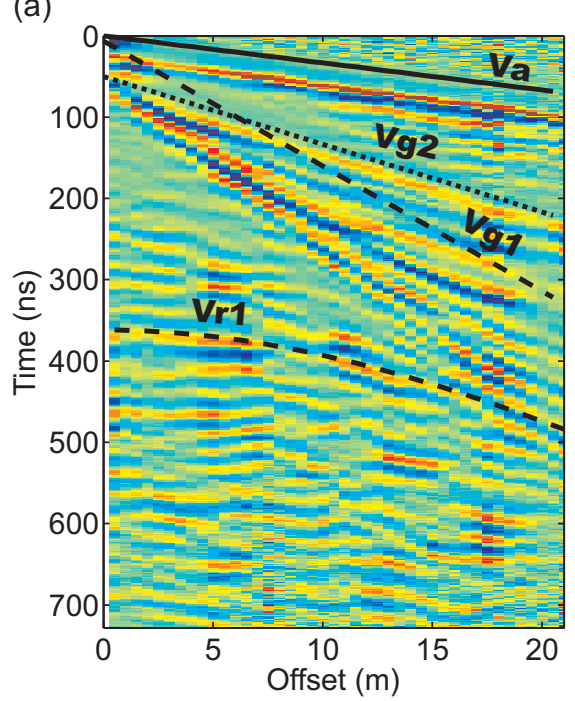

(b)

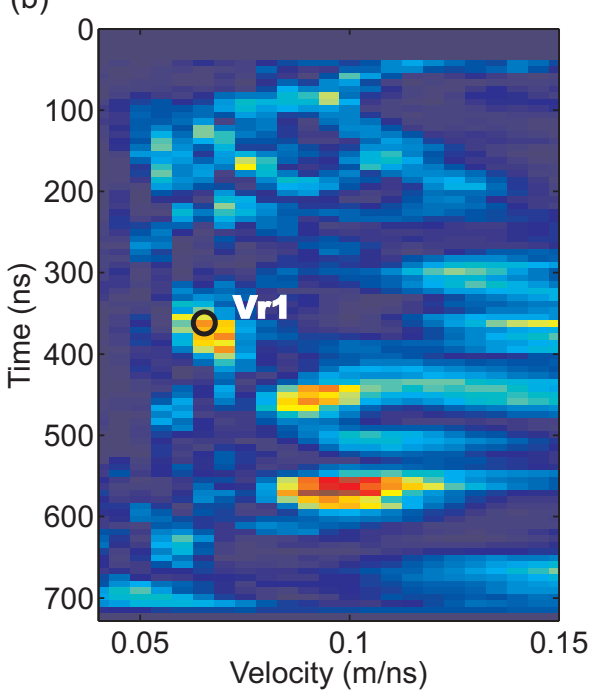

Fig. 5. (a) GPR data from CMP1, which was recorded using $50 \mathrm{MHz}$ antennas (location shown in Fig. 3a). Solid line shows the linear moveout of the picked airwave phase (Va); dashed lines show the linear moveout of a slow groundwave phase attributed to a thin soil layer (Vg1), and the normal moveout of a subsurface reflection ( $\mathrm{Vr} 1)$; dotted line shows the linear moveout of a second fast groundwave phase attributed to a substrate of bedrock underlying the meadow ( $\mathrm{Vg} 2$ ). (b) Corresponding semblance plot for which warmer colours represent higher values. Circle defines the normal moveout velocity calculated for picked reflection Vr1 shown in (a).

where $t_{i}$ is the zero-offset intercept time $(50 \mathrm{~ns}), v_{1}$ is the velocity of the soil layer $(0.065 \mathrm{~m} / \mathrm{ns})$, and $v_{2}$ is the velocity of the bedrock refractor $(0.12 \mathrm{~m} / \mathrm{ns})$. Based on our analysis, we calculate that the bedrock beneath CMP1 is no deeper than about $1.9 \mathrm{~m}$.

\subsection{Electrical resistivity tomography profiles}

Inverted electrical resistivity tomograms ERT1 and ERT2 that correspond to profiles GPR1 and GPR2 are shown in Fig. 6 (locations shown in Fig. 3a). To facilitate comparison with the GPR profiles, we have plotted the ERT tomograms as transparent overlays onto the processed GPR cross-sections. Parts of each ERT tomogram that are not well resolved (i.e., the model cells with DOI values $>0.2$ ) are not plotted. Most of the shallow parts of the model are well resolved and several structures can be interpreted. For example, the unconsolidated rubble of the talus cone corresponds to a high-resistivity layer $(>20000 \Omega \mathrm{m})$ with a maximum thickness of $\sim 5 \mathrm{~m}$. Resistivities within the underlying bedrock range from 5000 to $20000 \Omega \mathrm{m}$. The lowest resistivities generally occur near the surface of the bedrock, suggesting that small amounts of water may reside near the interface between the bedrock and talus rubble.

In contrast to profile ERT1, the tomogram for profile ERT2 exhibits a prominent low-resistivity layer $(<5000 \Omega \mathrm{m})$ underneath the part of the profile that crosses the meadow (Fig. 6b). The base of this layer is delineated at around $4 \mathrm{~m}$ depth by a sharp change to resistivities in excess of $20000 \Omega \mathrm{m}$. We suggest that this boundary represents a change from finegrained basin fill with relatively high clay and water content to a relatively low porosity bedrock substrate. Although the bedrock resistivities are much higher beneath the meadow than beneath the talus deposit, we do not interpret a change in bedrock composition and suggest that the high values are a consequence of overfitting the inverted resistivity data in this region. Furthermore, because the shallow temperature/moisture sensors that were installed beneath the meadow indicate a trend of increasing above-zero temperatures with increasing depths, we rule out the possibility that the high resistivities may indicate permafrost.

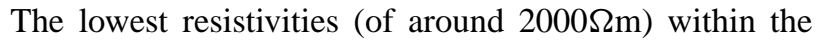
basin-fill layer coincide with the largest vertical differences (or travel-time lags) between the airwave and groundwave phases on the corresponding GPR cross-section (at around $x=80 \mathrm{~m}$ in Figs. $4 \mathrm{~b}$ and $6 \mathrm{~b}$ ). Consequently, the basin fill can be classified on the basis of both low electrical resistivities and low GPR velocities. Variations in resistivity and GPR velocity within this layer are probably controlled by a combination of changing grain size and/or water content. Toward the northern end of the profile, the low-resistivity layer extends laterally to about $x=105 \mathrm{~m}$, indicating that parts of the unvegetated talus between $x=85 \mathrm{~m}$ and $x=105 \mathrm{~m}$ are underlain by finer grained basin fill. In addition, at this location the groundwave phase on the corresponding GPR cross-section exhibits a travel-time lag characteristic of other parts of the low-velocity basin fill. We also note that near-surface resistivities increase sharply from around 5000 to $10000 \Omega \mathrm{m}$ 

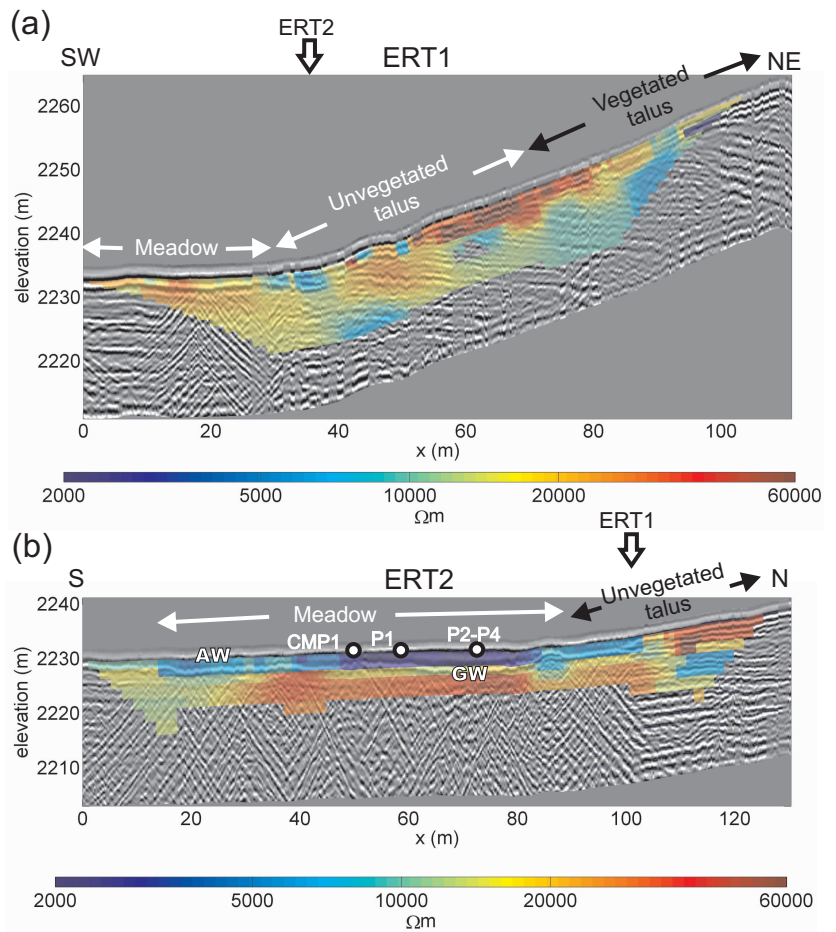

Fig. 6. As for Fig. 4, but with the corresponding inverted electrical resistivity tomograms ERT1 and ERT 2 overlain onto the GPR cross-sections. ERT model cells with DOI values $>0.2$ are not plotted (see text for explanation).

towards the southern end of the profile at the location of the bedrock saddle interpreted from profile GPR2 (at $x=16 \mathrm{~m}$ in Figs. $4 b$ and $6 b)$.

\subsection{Seismic refraction profile}

The seismic refraction profile coincides with portions of profiles GPR1 and ERT1 (dark blue line in Fig. 3a). First arrival picks from shot gathers recorded on the talus show two distinct velocity phases: (1) a slow shallow phase with velocities of around $500 \mathrm{~m} / \mathrm{s}$ associated with the talus cover and (2) a faster deeper phase with velocities of around $3500 \mathrm{~m} / \mathrm{s}$, indicating a change to higher velocity bedrock (e.g. Fig. 7).

The inverted $\mathrm{p}$-wave velocity tomogram for this profile and first-arrival raypaths computed for each shot-receiver combination are displayed in Fig. 8a. The reliability of the velocity calculated for each model cell is determined by the number of unique ray paths that cross each cell. Consequently, model cells between $x=0$ and $x=50 \mathrm{~m}$ and at depths less than about $10 \mathrm{~m}$ below the surface are better constrained than in other regions. In order to draw comparisons with the GPR data, we extracted only the parts of the seismic tomogram that we could interpret with confidence. Figure $8 b$ shows the cropped velocity tomogram plotted as a transparent overlay onto the corresponding GPR cross-section. In the tomogram, unconsolidated rubble comprising the talus corresponds to a

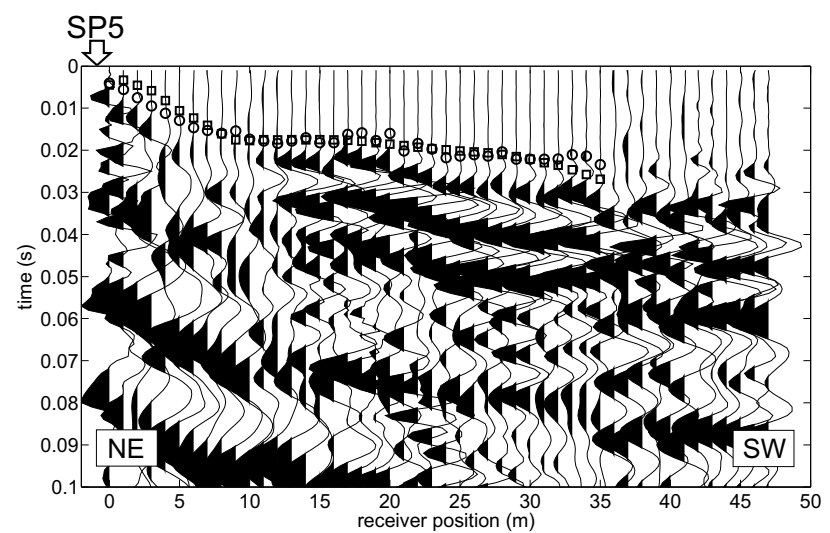

Fig. 7. Example shot gather recorded from shot point 5 (SP5), which was located on a talus deposit (the shot point location is shown on the seismic tomogram in Fig. 8). Circles are observed first-break picks and squares are calculated travel-times from the inverted velocity model.

near-surface layer of up to 4-6 $\mathrm{m}$ in thickness with velocities less than $1000 \mathrm{~m} / \mathrm{s}$. The low-velocity layer is underlain by a layer of higher velocities predominantly between 2000 and $4000 \mathrm{~m} / \mathrm{s}$, which corresponds to the region of bedrock interpreted from the GPR and ERT cross-sections. A thinner (2-4-m-thick) low-velocity layer also resides under the part of the profile that crosses the meadow.

\subsection{Bedrock topography and basin-fill volume}

By using our interpretations of the GPR and ERT profiles, we estimated the topography of the bedrock basin and dimensions of the basin fill that underlies the meadow. From the four ERT profiles that cross the meadow, we delineated the depth to the top of the bedrock on the basis of sharp changes from low resistivities (generally $<10000 \Omega \mathrm{m}$ ) to high resistivities (generally $>10000 \Omega$ m; Figs. 3a and 6). Because the groundwaves on most GPR profiles tended to obscure very shallow reflections and because strong electromagnetic-wave attenuation within the moist, clay-rich soil comprising the basin fill suppresses deeper reflections, we could not image the bedrock topography nor reflections from layering within the bedrock underlying the meadow. Nevertheless, as shown in Fig. 6b, the top of the bedrock surface imaged by the ERT data generally coincides with the location of the groundwave arrival as observed on the depth-corrected GPR crosssections. For this reason, we consider the vertical position of the groundwave on the depth-corrected GPR cross-sections to be a crude proxy for the maximum depth to bedrock beneath the meadow. If the bedrock were much deeper, we would expect to see a coherent reflection produced by the strong electromagnetic contrast between the soil layer and bedrock. 


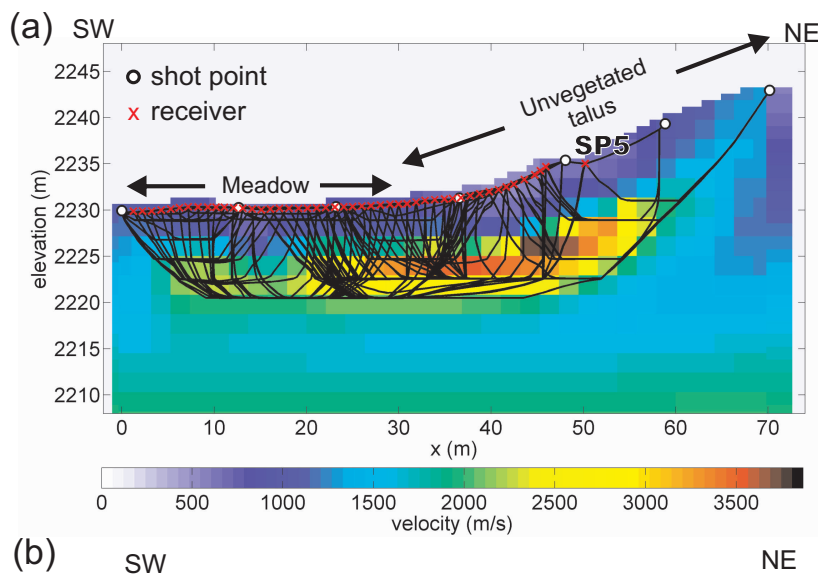

(b)

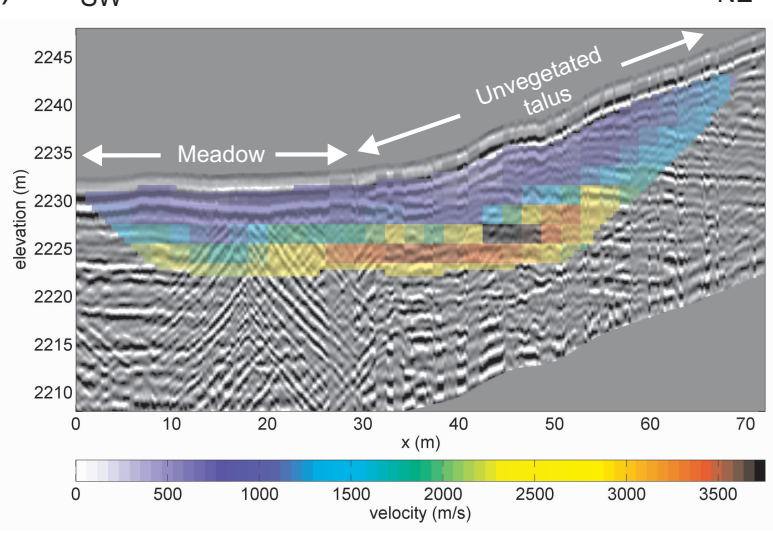

Fig. 8. (a) Inverted p-wave velocity tomogram for the seismic refraction profile (location shown in Fig. 3a). Shot-receiver raypaths calculated for the model are plotted as black lines. Shot gather data from shot point SP5 are shown in Fig. 7. (b) The same p-wave velocity tomogram as shown in (a) but plotted as a transparent overlay onto the corresponding cross-section for profile GPR1. Regions of the model that are not traversed by the raypaths shown in (a) are not plotted.

On the depth-corrected GPR cross-sections, variations in the arrival depth of the groundwave phase provide a qualitative indicator of lateral changes in the depth to bedrock beneath the meadow; where the groundwave phase shallows the bedrock surface must also shallow and, conversely, where the groundwave phase deepens the bedrock must deepen. Thus, on the depth-corrected GPR cross-sections, ground wave phase arrivals were used as a proxy for the elevation of the bedrock interface. Because our seismic velocity tomogram has a coarser resolution than the ERT and GPR images, we do not use it to determine the topography of the bedrock surface under the meadow.

By using the MATLAB "griddata" algorithm based on Delaunay triangulation, we interpolated bedrock elevation picks from the GPR and ERT profiles over the entire surface area of the meadow $\left(2100 \mathrm{~m}^{2}\right)$. This surface was then subtracted from the DEM of the meadow topography to produce a depth-to-bedrock surface. Contoured maps of meadow ele- vation, bedrock elevation, and depth to bedrock are shown in Fig. 9. In general, the basin is deepest beneath the long axis of the meadow, reaching a maximum depth of just over $4 \mathrm{~m}$ between the cluster of piezometers $\mathrm{P} 2-\mathrm{P} 4$ and piezometer $\mathrm{P} 1$ (Fig. 9c). Based on our estimate of basin geometry, we determined that the basin fill has a total volume of ca. $3300 \mathrm{~m}^{3}$. As shown in Fig. 6b, where the surface stream channel crosses the southern and lowest end of the meadow, the underlying bedrock topography forms a saddle with an elevation of ca. $2230 \mathrm{~m}$.

\subsection{Hydrological fluxes and water table dynamics}

The average snow depth and standard deviation at the site in April was $1.8 \pm 0.4 \mathrm{~m}$ in 2007 , and $1.4 \pm 0.2 \mathrm{~m}$ in 2008 ; and SWE was $610 \pm 210 \mathrm{~mm}$ in 2007 and $380 \pm 90 \mathrm{~mm}$ in 2008 . Snow melt occurred during May and June in both years, and the site was essentially snow free by early July. The amount of precipitation between the time of each snow survey and June 30 was $256 \mathrm{~mm}$ in 2007 and $253 \mathrm{~mm}$ in 2008. Therefore, the site received approximately $870 \mathrm{~mm}$ of vertical water input during the snowmelt period in 2007 , and $630 \mathrm{~mm}$ in 2008. As the meadow vegetation was growing during the snow-free season of 1 July-30 September, the total amount of precipitation was $231 \mathrm{~mm}$ in 2007 and $284 \mathrm{~mm}$ in 2008 . Figure 10a shows daily precipitation for 2008.

The soil in the meadow had a silt loam texture from the surface to a depth of $0.8-0.9 \mathrm{~m}$. A silty clay layer containing rock fragments occurred at $0.9-1.1 \mathrm{~m}$. Volumetric water content of the five soil samples collected from depths of $0.09-0.95 \mathrm{~m}$ on 11 July 2007 ranged from 0.62 to 0.75 with no particular depth trends. The water table observed in the soil pit was within $0.1-0.2 \mathrm{~m}$ of the ground surface, indicating nearly saturated conditions for all soil samples.

Two ring-infiltrometer measurements gave the saturated hydraulic conductivity of the surface soil $(0-0.25 \mathrm{~m}$ depth $)$ of $1.4 \times 10^{-5} \mathrm{~m} / \mathrm{s}$ and $7.0 \times 10^{-6} \mathrm{~m} / \mathrm{s}$. Considering that ring infiltrometers have a tendency to overestimate conductivity due to the lateral flow divergence under the ring, the actual conductivity value is expected to be as low as half of these values (Reynolds et al., 2002, Eqs. 3.4-14). A slug test on piezometer P4, screened $0.77-1.07 \mathrm{~m}$ below the ground surface, gave the saturated conductivity of $2.5 \times 10^{-7} \mathrm{~m} / \mathrm{s}$.

The piezometers were installed in July and August of 2007, and as such, complete water level time series are only available for 2008. The water level in piezometer P4 stayed near the ground surface during the snow melt period in late June of 2008 (Fig. 10b) and rapidly declined at the end of snow melt. After the water level declined to approximately $0.35 \mathrm{~m}$ below the ground surface on $8 \mathrm{July}$, the rate of decline decreased dramatically to $7 \mathrm{~mm} / \mathrm{d}$. The water level quickly responded to rain events and rose close to the surface during the events of 9, 21, and 29 August (Fig. 10a and b). These quick rises were followed by a rapid decline of water level to $0.35 \mathrm{~m}$ below the ground surface and a very 

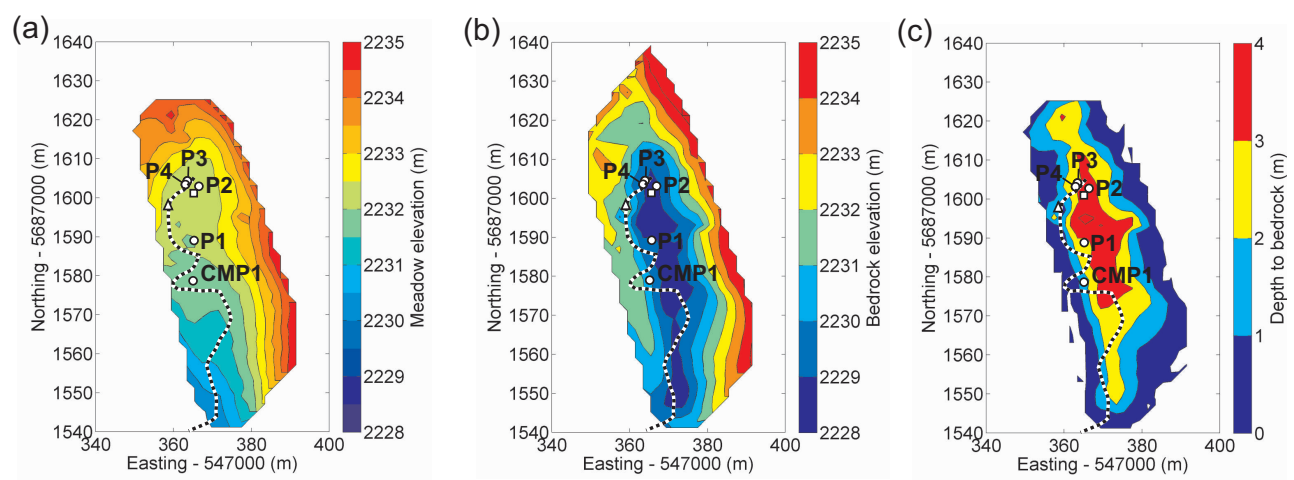

Fig. 9. Contoured maps of (a) meadow topography from 2-m LIDAR DEM, (b) subsurface bedrock topography produced by interpolating bedrock picks made on ERT and GPR profiles, and (c) depth to bedrock produced by differencing (a) and (b). Dotted line - surface stream channel; circles - piezometers P1-P4 and the center of the CMP1 GPR profile; triangle - monitoring weir; square - excavated soil pit.

slow decline thereafter, similar to the water level response after the snow melt. A continuous time series was available only from P4, but the manual biweekly measurements in P1 and $\mathrm{P} 2$ indicated that the water level in these piezometers remained nearly constant at $2231.9 \mathrm{~m}$ a.m.s.l. Since the screens of these piezometers are located within $1 \mathrm{~m}$ of the ground surface, and they all behaved similarly, the water level fluctuations in these piezometers represent the water table dynamics under the meadow. Piezometer P1, the shallowest of the four piezometers, went dry after 9 July. All three soil moisture sensors at depths of $0.37,0.63$, and $0.90 \mathrm{~m}$ registered nearly constant values near or at saturation throughout June-September 2008, indicating that the water table never dropped more than $0.4-0.5 \mathrm{~m}$ below the ground surface.

The record of channel discharge was available only after 22 July 2008 (Fig. 10c). The channel discharge had sharp peaks corresponding to rain events, and maintained a very small amount of baseflow. The total flow volume during 22 July-30 September was $2400 \mathrm{~m}^{3}$. Water samples were collected from the channel during July-September 2007. Water was generally dilute and had total dissolved species (TDS) concentrations ranging from 14 to $21 \mathrm{mg} / \mathrm{L}$ and major ion compositions characterized by $(\mathrm{Ca}, \mathrm{Mg})-\mathrm{HCO}_{3}$. There was no obvious seasonal trend in TDS or composition.

\section{Discussion: synthesis of geophysical and hydrological results}

Based on the geophysical and hydrological results, a conceptual diagram of the talus-meadow complex has been developed (Fig. 11). The talus is situated at the toe of a sequence of steep bedrock cliffs rising to a total height of $500 \mathrm{~m}$. Since there is little storage capacity in the cliff sequence, much of the snowmelt and rain flows down and enters the talus. The cliff runoff and direct precipitation inputs into the talus flow through a relatively thin saturated layer at the sedimentbedrock interface, and provide a lateral water input to the
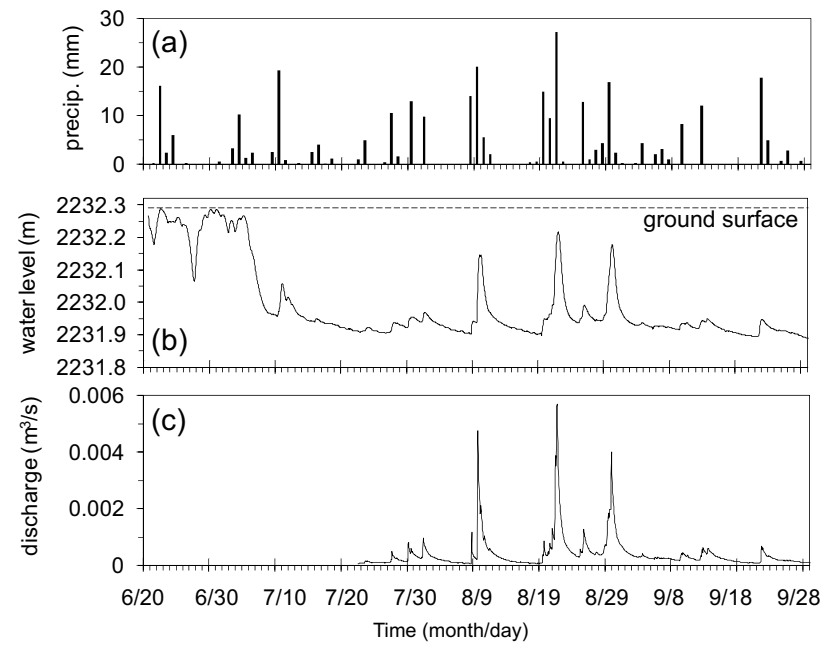

Fig. 10. Hydrological data for June-September, 2008. (a) Daily precipitation. (b) Elevation (above mean sea level) of the water level in piezometer P4. Dashed line indicates the ground surface at this location. (c) Discharge measured at the weir. See Figs. 3a and 9 for the location of P4 and the weir.

meadow. It is impossible to estimate the area of the cliffs and talus contributing runoff to the meadow due to the complex topography, but the contributing area is expected to be on the order of 20000 to $50000 \mathrm{~m}^{2}$. In contrast, the area of meadow is $2100 \mathrm{~m}^{2}$.

The meadow is underlain by up to $4 \mathrm{~m}$ of relatively fine sediments containing rock fragments (Fig. 9c). At this location, the bedrock layers dip towards the cliff at a low angle of $10^{\circ}$, which may have contributed to the formation of an oval shaped bedrock basin that trapped fine sediments. The water table dynamics in the meadow is characterized by a very stable condition confined to a narrow range, punctuated by rapid rises and recessions in response to snowmelt and rain events (Fig. 10b). Based on this behavior, we interpret 


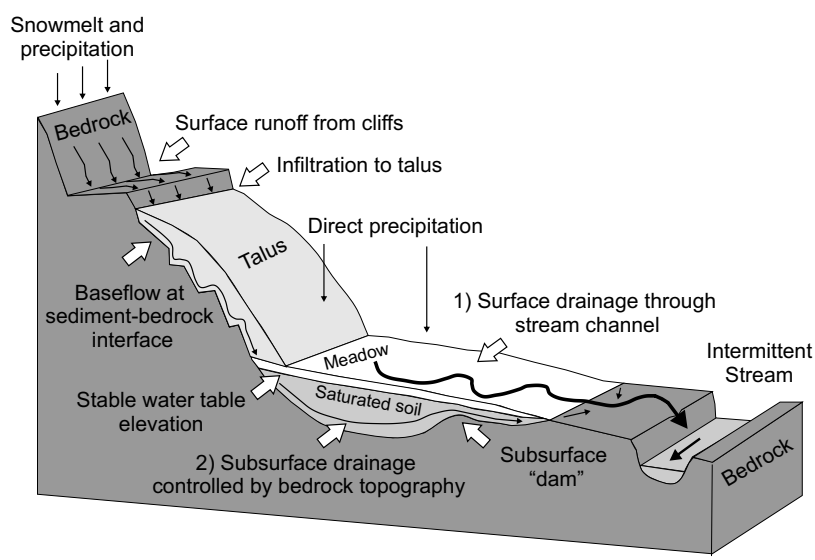

Fig. 11. Schematic diagram showing the internal structure and groundwater and surface water flow pathways in the talus-meadow complex.

a threshold for water-table stability at an approximate elevation of $2231.9 \mathrm{~m}$. Since there was no obvious change in soil texture at this elevation, and all three piezometers with sufficiently deep screens behaved similarly, the threshold behavior is most likely controlled by the drainage mechanisms of the entire meadow basin. We hypothesize two possible mechanisms, (1) surface drainage through the stream channel and (2) subsurface drainage controlled by bedrock topography. To examine the first mechanism, we note that the channel had continuous flow throughout July-September (Fig. 10c), and the channel water level fluctuated within a narrow range $(0.05-0.1 \mathrm{~m})$. This indicates that the water table under the meadow never dropped below the channel bed. Under this condition, assuming that the hydraulic conductivity of soil is reasonably homogeneous, the groundwater drainage rate can be determined by the difference between piezometer water levels and the channel water level. This mechanism can explain the exponential decline of the water table after the storm peak. The second mechanism involves a "saddle" in bedrock topography that limits the overflow of groundwater after the water table drops below the saddle. This mechanism is referred to as "fill and spill" in the hillslope hydrology literature (e.g. Spence and Woo, 2003; Tromp-van Meerveld and McDonnell, 2006). The shape of the bedrock basin indicates a saddle at the south end of the meadow (Fig. 9b). However, the elevation of the saddle (ca. $2230 \mathrm{~m}$ ) is much lower than the elevation of the water table (ca. $2231.9 \mathrm{~m}$ ) during stable periods (Fig. 10b), implying that the simple fill-and-spill mechanism cannot explain the threshold behavior. It is more likely that the saddle reduces the effective thickness of saturated soil, which results in reduced transmissivity and increased flow resistance. Consequently, the saddle also reduces hydraulic gradient between the south end of the basin and the deepest part in the middle by serving as a subsurface "dam". It is probably the combi- nation of several mechanisms that maintains the stable depth to the water table $(0.3-0.4 \mathrm{~m})$ under the meadow during dry periods.

Based on the geophysical data, the total volume of basin fill is estimated to be $3300 \mathrm{~m}^{3}$. By assuming a porosity of 0.6 , the total volume of groundwater that can be stored under the meadow basin is approximately $2000 \mathrm{~m}^{3}$. During 22 July-30 September 2008, approximately $2400 \mathrm{~m}^{3}$ of water was discharged through the channel, implying that more than one total storage volume of water flowed through the system during this period. Considering that the amount of precipitation during this period was $235 \mathrm{~mm}$ and mean annual precipitation is $1000-1200 \mathrm{~mm}$, it is likely that groundwater under the meadow is flushed several times in a year. The high rate of flushing, or short residence time, explains the low concentration of dissolved species in the water sampled from the channel, which is fed by groundwater.

\section{Conclusions}

The internal structures of a talus-meadow complex and its hydrological functions were examined using geophysical imaging and by monitoring water-table fluctuations and hydrological fluxes. Analysis of ground-penetrating radar (GPR) and seismic refraction profile data allowed the topography of bedrock underlying the talus and meadow to be delineated. These interpretations were consistent with results from additional electrical resistivity tomography (ERT) profiles, which showed a high contrast between the resistivity of wet meadow sediments and underlying bedrock. The meadow is underlain by fine-grained high-porosity $(>0.6)$ sediments that were deposited in a narrow, north-south trending basin, which reaches maximum depths of ca. $4 \mathrm{~m}$. The water table in the meadow basin fluctuates rapidly between the ground surface and 0.3 to $0.4 \mathrm{~m}$ depth in response to snowmelt and rain. Very stable conditions are attained after the water table declines below these depths.

The relatively shallow water table provides a steady supply of water to meadow grasses, which in turn sustain the alpine fauna dependent on vegetation. The stable water table is maintained during summer months by the supply of rainfall runoff from the talus and the cliffs above, and also possibly by the presence of the bedrock saddle, which restricts the subsurface drainage out of the basin. The input volume of snowmelt and rainfall is several times greater than the total storage volume in the meadow basin, implying a relatively short residence time of groundwater. This results in a low concentration $(14-21 \mathrm{mg} / \mathrm{L})$ of dissolved solids in groundwater feeding the stream that drains the meadow.

The particular talus-meadow complex studied may not represent all types of talus-meadow systems that occur in alpine environments. However, the insights gained from this study are useful for improving our overall understanding of the hydrological and ecological functions of alpine 
talus-meadow systems. For example, the contribution of runoff from cliff sequences and the effects of bedrock topography on subsurface drainage are expected to be present in many alpine environments. Further studies should examine the roles of various types of talus-meadow systems in modulating basin-scale runoff and water quality (e.g. nutrient concentration), and also on the hydrological function of other types of groundwater storage units, such as proglacial moraine.

Acknowledgements. We thank Jaime Hood, Greg Langston, James Roy, Jackie Randell, Nathan Green, Sarah Forte, Joshua Ouellet, Simon Martin, Jane Simmons, Ian Anderson, and Raymond Wong for field assistance; Parks Canada and Lake O'Hara Lodge for logistical support; Chris Hopkinson for digital elevation data; and Hansruedi Maurer of ETH Zurich for use of the INV2D seismic tomography code. Funding was provided by Alberta Ingenuity Centre for Water Research, Environment Canada Science Horizons Program, G8 Legacy Chair in Wildlife Ecology, Natural Sciences and Engineering Research Council, the Canadian Foundation for Climate and Atmospheric Sciences (IP3 Network), and a Swiss National Science Foundation post-doctoral fellowship for the lead author.

Edited by: S. Carey

\section{References}

Annan, A. P.: Ground-penetrating radar, in: Near-surface geophysics, edited by: Butler, D. K., Society of Exploration Geophysics, Tulsa, Oklahoma, USA, 357-438, 2005

Bales, R. C., Molotch, N. P., Painter, T. H., Dettinger, M. D., Rice, R., and Dozier, J.: Mountain hydrology in the western United States, Water Resour. Res., 42, W08432, doi:10.1029/2005WR004387, 2006.

Ballantyne, C. K.: Paraglacial geomorphology, Quaternary Sci. Rev., 21, 1935-2017, 2002.

Beres, M., Huggenberger, P., Green, A. G., and Horstmeyer, H.: A study of glaciofluvial architectures using two and threedimensional georadar methods, Sediment. Geol., 129, 1-24, 1999.

Bertran, P., Hetu, B., Texier, J., and van Steijn, H.: Fabric characteristics of subaerial slope deposits, Sedimentology, 44, 1-16, 1997.

Caballero, Y., Jomelli, V., Chevallier, P., and Ribstein, P.: Hydrological characteristics of slope deposits in high tropical mountains (Cordillera Real, Bolivia), Catena, 47, 101-116, 2002.

Campbell, D. H., Clow, D. W., Ingersoll, G. P., Nast, M. A., Spahr, N. E., and Turk, J. T.: Processes controlling the chemistry of two snowmelt-dominated streams in the Rocky Mountains, Water Resour. Res., 31, 2811-2821, 1995.

Clow, D. W., Schrott, L., Webb, R., Campbell, D. H., Torizzo, A., and Dorblaser, M.: Ground water occurence and contributions to streamflow in an alpine catchment, Colorado Front range, Ground Water, 41, 937-950, 2003.
Dahlin, T. and Zhou, B.: A numerical comparison of 2-D resistivity imaging with 10 electrode arrays, Geophys. Prospect., 52, 379 398, 2004.

Davis, J. L., Heginbottom, J. L., Annan, A. P., Daniels, R. S., Berdal, B. P., Bergan, T., Duncan, K. E., Lewin, P. K., Oxford, J. S., Roberts, N., Skehel, J. J., and Smith, C. R.: Ground penetrating radar surveys to locate 1918 Spanish Flu victims in permafrost, J. Forensic Sci., 45, 68-76, 2000.

Freeze, R. A. and Cherry, J. A.: Groundwater, Prentice-Hall, 604 pp., 1979.

Gross, R., Green, A. G., Horstmeyer, H., and Holliger, K.: 3-D georadar images of an active fault: efficient data acquisition, processing and interpretation strategies, P. Soc. Photo-Opt. Ins., 4, 19-40, 2003.

Hislop, A.: Structural geology of the Opabin Plateau. B. Sc. Thesis, University of Calgary, 30 pp., 2008.

Hood, J. L., Roy, J. W., and Hayashi, M.: Importance of groundwater in the water balance of an alpine headwater lake, Geophys Res. Lett., 33, L13405, doi:10.1029/2006GL026611, 2006.

Hoffmann, T. and Schrott, L.: Modelling sediment thickness and rockwall retreat in an Alpine valley using 2-D-seismic refraction (Reintal, Bavarian Alps), Z. Geomorphol. N. F. Supplementband, 127, 153-173, 2002.

Hvorslev, M. J.: Time lag and soil permeability in groundwater observations, Bulletin No. 36, Corps of Engineers, US Army, Waterways Experiment Station, 1951.

Jol, H. M. and Smith, D. G.: Ground penetrating radar of northern lacustrine deltas, Can. J. Earth Sci., 28, 1939-1947, 1991.

Jomelli, V. and Francou, B.: Comparing the characteristics of rockfall talus and snow avalanche landforms in an Apline environment using a new methodological approach: Massif des Ecrins, French Alps, Geomorphology, 35, 181-192, 2000.

Kattelmann, R. and Elder, K.: Hydrologic characteristics and water balance of an alpine basin in the Sierra Nevada, Water Resour. Res., 27, 1553-1562, 1991.

Kearey, P. and Brooks, M.: An introduction to geophysical exploration, Blackwell Scientific Publications, 254 pp., 1991.

Kneisel, C., Hauck, C., and Vonder Mühll, D. S.: Permafrost below the timberline confirmed and characterized by geoelectrical resistivity measurements, Bever Valley, eastern Swiss Alps, Permafrost Periglac. Process., 11, 295-304, 2000.

Lanz, E., Maurer, H., and Green, A. G.: Refraction tomography over a buried waste disposal site, Geophysics, 63, 1414-1433, 1998.

Liu, F., Williams, M. W., and Caine, N.: Source waters and flow paths in an alpine catchment, Colorado Front Range, United States, Water Resour. Res., 40, W09401, doi:10.1029/2004WR003076, 2004.

Loheide, S. P., Deitchman, R. S., Cooper, D. J., Wolf, E. C., Hammersmark, C. T. and Lundquist, J. D.: A framework for understanding the hydroecology of impacted wet meadows in the Sierra Nevada and Cascade Ranges, California, USA, Hydrogeol. J., 17, 229-246, 2009.

Loke, M. H. and Barker, R. D.: Rapid least-squares inversion of apparent resistivity pseudosections using a quasi-Newton method, Geophys. Prospect., 44, 131-152, 1996.

Loke, M. H. and Dahlin, T.: A comparison of the Gauss-Newton and quasi-Newton methods in resistivity imaging inversion, J. Appl. Geophys., 49, 149-162, 2002. 
Marescot, L., Loke, M. H., Chapellier, D., Delaloye, R., Lambiel, C., and Reynard, E.: Assessing reliability of 2-D resistivity imaging in mountain permafrost studies using the depth of investigation index method, Near Surf. Geophys., 1, 57-67, 2003.

Maurer, H. and Hauck, C.: Instruments and methods: Geophysical imaging of alpine rock glaciers, J. Glaciol., 53, 110-120, 2007.

Moran, M. L., Greenfield, R. J., and Arcone, S. A.: Delineation of a complexly dipping temperate glacier bed using short-pulse radar arrays, J. Glaciol., 46, 274-286, 2000.

Musil, M., Maurer, H., Green, A. G., Horstmeyer, H., Nitsche, F. O., Vonder Mühll, D., and Springman, S.: Shallow seismic surveying of an Alpine rock glacier, Geophysics, 67, 1701-1710, 2002.

Oldenburg, D. W. and Li, Y. G.: Estimating depth of investigation in dc resistivity and IP surveys, Geophysics, 64, 403-416, 1999.

Pierson, T. C.: Classification and hydrological characteristics of scree slope deposits in the northern Craigieburn Range, New Zealand, J. Hydrol.(N.Z.), 21, 34-60, 1982.

Price, R. A., Cook, D. G., Aitken, J. D., and Mountjoy, E. W.: Geology, Lake Louise, Alberta and British Columbia. Map 1483A, scale 1:50 000, Geological Survey of Canada, Ottawa, 1980.

Reynolds, W. D., Elrick, D. E., and Youngs, E. G.: Single-ring and double or concentric ring infiltrometers, in Methods of Soil Analysis, Part 4. Physical Methods, Soil Science Society of America Book Series 5, edited by: Dane, J. H. and Topp, G. C., 821-826, Madison, Wisconsin, 2002.

Roach, W. J., Huntly, N., and Inouye, R.: Talus fragmentation mitigates the effects of pikas, Ochotona princeps, on high alpine meadows, OIKOS, 92, 315-324, 2001.

Sass, O.: Determination of the internal structure of alpine talus deposits using different geophysical methods (Lechtaler Alps, Austria), Geomorphology, 80, 45-58, 2006.
Sass, O.: Bedrock detection and talus thickness assessment in the European Alps using geophysical methods, J. Appl. Geophys., 62, 254-269, 2007.

Sass, O. and Wollny, K.: Investigations regarding alpine talus slopes using ground-penetrating radar (GPR) in the Bavarian Alps, Germany, Earth Surf. Proc. Land, 26, 1071-1086, 2001.

Schrott, L., Hufschmidt, G., Hankammer, M., Hoffmann, T., and Dikau, R.: Spatial distribution of sediment storage types and quantification of valley fill deposits in an alpine basin, Reintal, Bavarian Alps, Germany, Geomorphology, 55, 45-63, 2003.

Spence, C. and Woo, M.-K.: Hydrology of subarctic Canadian shield: soil-filled valleys, J. Hydrol., 279, 151-166, 2003.

Sueker, J. K., Clow, D. W., Ryan, J. N. and Jarrett, R. D.: Effect of basin physical characteristics on solute fluxes in nine alpine/subalpine basins, Colorado, USA, Hydrol. Process., 15, 2749-2769, 2001.

Sueker, J. K., Ryan, J. N., Kendall, C., and Jarrett, R. D.: Determination of hydrological pathways during snowmelt for alpine/subalpine basins, Rocky Mountain National Park, Colorado, Water Resour. Res., 36, 63-75, 2000.

Tromp-van Meerveld, H. J. and McDonnell, J. J.: Threshold relations in subsurface stormflow: 2. The fill and spill hypothesis Water Resour. Res., 42, W02411, doi:10.1029/2004WR003800, 2006.

White, S. E.: Alpine mass movement forms (noncatastrophic): classification, description, and significance, Arctic Alpine Res., 13, 127-137, 1981.

Zelt, C. A. and Smith, R. B.: Seismic traveltime inversion for 2-D crustal velocity structure, Geophys. J. Int., 108, 16-34, 1992. 